\title{
DESIGN OF ACADEMIC ORGANIZATION PERFORMANCE MEASUREMENT SYSTEM
}

\author{
Edy Susanto, Ahmadi, Benny Sukandari. \\ ${ }^{1}$ Indonesian Naval Technology College, \\ Bumimoro-Morokrembangan, Surabaya 60187, Indonesia
}

\begin{abstract}
The Naval Academy must spur its potential to be able to compete with other tertiary institutions. To make it happen certainly need a good improvement. The Navy Academy's performance evaluation system in terms of operational and administrative aspects is not optimal. Based on the planned improvement of the Naval Academy which is compiled annually it is still needed. The report on the implementation of work programs and budgets at the end of the year is not yet sufficient to measure the actual performance of the Navy Academy, by the required assessment system that can be used by management to improve performance and performance at the Navy Academy. The results of this evaluation are very important for the planning and determination of strategic steps and strategies to achieve the vision, mission and coordination objectives. Research Methods that Support Performance Measurement Systems using the Balanced Scorecard method. The design of a performance appraisal system that is in accordance with the concept of the Balanced Scorecard in this study used 8 strategic objectives as a criterion for evaluating the performance of tertiary institutions consisting of 27 KPIs.
\end{abstract}

Keywords: Performance Measurement, Framework, Balanced Scorecard.

\section{INTRODUCTION}

Naval Academy (AAL) is an Indonesian Navy Navy educational institute located in the city of Surabaya which prints cadets to become candidates for officers with the spirit of Pancasila and Saptamarga fighters, possessing knowledge and skills of the marine dimension profession in the initial assignment spectrum in KRI / troops and have managerial skills and leadership as candidates for leadership of the Navy / Navy. Educating cadets for four years to be appointed as Navy officers with the rank of Second Lieutenant and entitled to hold a Bachelor of Applied Defense (S.ST.Han). Organizationally, AAL is within the Navy's organizational structure and is under the guidance of the TNI Academy led by an AAL Governor.

AAL's success in achieving its vision and mission is inseparable from AAL's good performance. Based on this it can be concluded that good performance is an important aspect in supporting efforts to achieve the vision and mission of an organization. Performance measurement is useful for comparing expected results with actual results, investigating deviations in plans, evaluating individual performance and assessing the developments that occur in achieving the goals set. The performance measurement process is continuous in the form of cycles that are interrelated and uninterrupted.

The Naval Academy as an organization under the Indonesian Navy is always required to improve its performance in carrying out its main tasks. So that there is a need for precise performance measures that are easily controlled by the management of the Naval Academy. The vision of the Naval Academy in accordance with its main task is "The realization of the Naval Academy that is Able to Produce Responsible Navy Officers, Tanggon and Trengginas". To realize this vision, a performance measurement system is needed that can improve the quality of education so as to know the strengths and weaknesses of AAL management.

\section{MATERIALS AND METHODS}

\subsection{Performance and Performance Measurement}

Performance measurement is useful for comparing expected results with actual results, investigating deviations in plans, evaluating individual performance, and assessing the developments that occur in achieving the goals set. The performance measurement process is continuous in the form of cycles that are interrelated and uninterrupted.

Performance measurement is useful for comparing expected results with actual results, investigating deviations in plans, evaluating individual performance, and assessing the developments that occur in achieving the goals set. The performance measurement process is continuous in the form of cycles that are interrelated and uninterrupted. In general, traditional management systems measure performance only focusing on the budget (budgets), so that the implementation of corporate strategy is very dependent on the available budget. (llyas, 2000) explains that the usefulness of performance appraisal is as follows: 
a. To correct the erroneous performance of work by employees, and as input for managers in assisting and directing employees.

b. To carry out repairs and improvements to other HR management activities such as promotions, training, salaries and incentives.

\subsection{Models of Performance Measurement Systems.}

According to Neely et. al. (1995), at present, an integrated performance measurement system that is popular and widely used in the industrial world, there are three models namely: the Balanced Scorecard from Harvard Business School, the Integrated Performance Measurement System (IPMS) from the Center for Strategic Manufacturing University of Strathclyde, and Performance Prism from collaboration between Accenture and Cranfield School of Management. All three meet the criteria for a fairly complete measurement that is comprehensive, integrative, and assesses internal and external aspects of the company.

\subsection{Balanced Scorecard}

The Balanced Scorecard was developed at Harvard Business School by Kaplan and Norton (1992). Until now the Balanced Scorecard is the most popular model for a new performance measurement system that has been developed (Neely et al., 1995). The Balanced Scorecard framework uses four perspectives with the starting point of the strategy as the basis for its design. The four perspectives include: financial perspective, customer perspective, internal business process perspective and learning and growth perspective. The relationship between objectives and performance measures is expressed by cause-andeffect relationships, where the culmination of performance occurs in financial perspective.

\subsection{Performance Measurement Framework with the Balanced Scorecard.}

In implementing a balanced scorecard to measure performance, there is a framework consisting of 4 stages that must be carried out to produce a scorecard as a performance measurement tool. The 4 stages are illustrated in a block diagram in Figs.

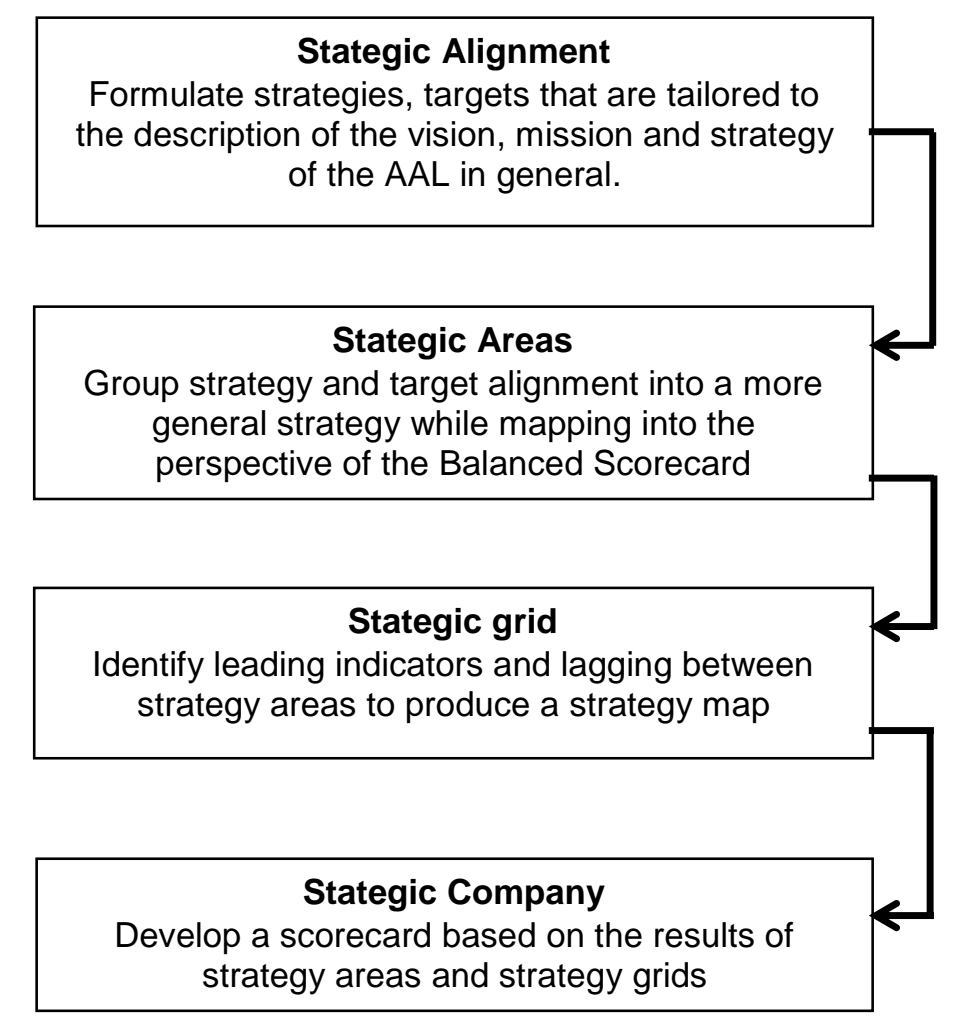

Figure 1. Performance Measurement Framework Using the Balanced Scorecard

\section{RESULTS AND DISCUSSION.}

In general, the application of the balanced scorecard at $\mathrm{AAL}$ as an educational institution refers to the strategy adopted. Before implementing the existing framework, this chapter defines the vision, mission, goals and strategies of the AAL.
AAL's vision is the realization of the Naval Academy that is able to produce Navy officers who are responsive, Tanggon and Trengginas

AAL's mission is:

1) Carrying out an educational process consisting of effective and efficient teaching, training and care to produce graduates of TNI AL 
officers who are of a fighting spirit, professional, disciplined, proud, hard working and smart work and have high physical fitness, through the application of management and educational technology appropriately.

2) Carrying out continuous education evaluation in order to improve the quality of education towards better, innovative and beneficial development.

3) Developing character education based on moral values and academic ethics to build a civilized and civilized environment of the military environment among the academic community.

Based on the vision and mission that has been applied at the Naval Academy, the vision and mission can be reduced to strategic objectives in the four perspectives of the Balanced Scorecard, namely finance, customers / patients, internal business processes and learning and growth.

\subsection{Determination of performance measures to achieve strategic goals (KPI).}

Strategic objectives are formulated to realize the vision, mission and objectives of the Naval Academy. Achievement of goals must have a measure used as an indicator of whether or not the desired target is achieved. There are two measures to measure the success of strategic objectives, namely:

a. The outcome measure (outcome measurment) is a lag indicator

b. Measuring performance drivers or boosters (performance driver measurement) as a lead indicator

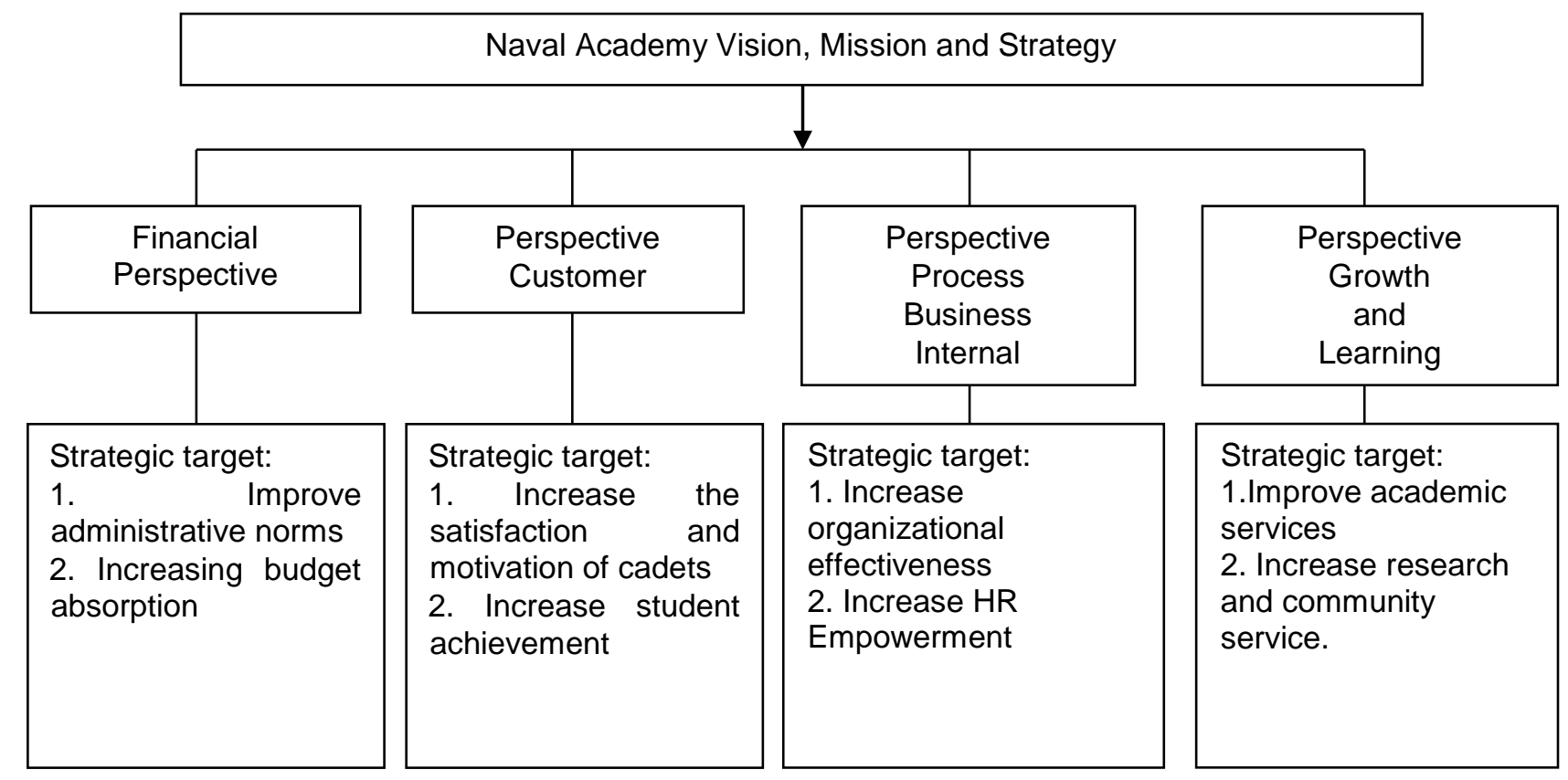

\subsection{Implementation of Performance Measurement}

This chapter explains the work steps taken in implementing the balanced scorecard as a measurement tool for $A A L$ performance in accordance with the framework.

a. Strategic Alignment

Based on the vision, mission, and strategy of the company / institution, strategic goals must be

formulated, namely the strategies that must be implemented and the targets to be achieved by AAL. The target must have clear measurement parameters. Table 2 is one example of strategic alignment obtained from one of the AAL strategy descriptions.

Table 2 Example of AAL strategic alignment

\begin{tabular}{|l|c|}
\hline \multicolumn{1}{|c|}{ Strategi } & Target \\
\hline Students graduate on time & $100 \%$ \\
\hline $\begin{array}{l}\text { Graduates who get a GPA } \\
\text { of } 3 \text { on a scale of } 4\end{array}$ & $\geq 90 \%$ \\
\hline Paper publication & $\geq 50 \%$ \\
\hline Student Kesamaptaan & $100 \%$ \\
\hline
\end{tabular}




\section{b. Strategic Areas}

At this stage, the strategies and targets that have been formulated at the strategic alignment stage are grouped into more general categories. The results of this categorization will then be mapped into the Balanced Scorecard perspective so that the area covered by this strategy is obtained. At AAL, there were 8 strategic areas which were generalizations from several strategies obtained at the strategy alignment stage. Then several strategic areas will be mapped to the perspective of the appropriate balanced scorecard. Table 3 shows the strategic areas obtained from generalizing the strategic alignment in Table 2. The strategic areas obtained in this example are then mapped into the customer's perspective.

Table 3 Examples of AAL strategic areas.

\begin{tabular}{|c|c|c|}
\hline Perspektif & $\begin{array}{l}\text { Strategic } \\
\text { Areas }\end{array}$ & Strategi \\
\hline \multirow{3}{*}{ Customer } & \multirow{3}{*}{$\begin{array}{l}\text { Improving student } \\
\text { achievement }\end{array}$} & \begin{tabular}{|l|} 
Students graduate on time \\
Graduates who get a GPA of 3 on \\
a scale of 4
\end{tabular} \\
\hline & & Paper publication \\
\hline & & Student Kesamaptaan \\
\hline
\end{tabular}

\section{c. Strategic Grid}

After obtaining strategic areas, the next step is to carry out a strategy grid, which is to identify leading indicators and lagging between existing strategic areas so that a causal relationship is obtained that refers to the realization of the company's / institutional vision and mission. The results of this strategy grid are in the form of a strategy map, which is a diagram that shows the relationship between the perspective of the balanced scorecard and the strategy to achieve the vision and mission of the company/ institution

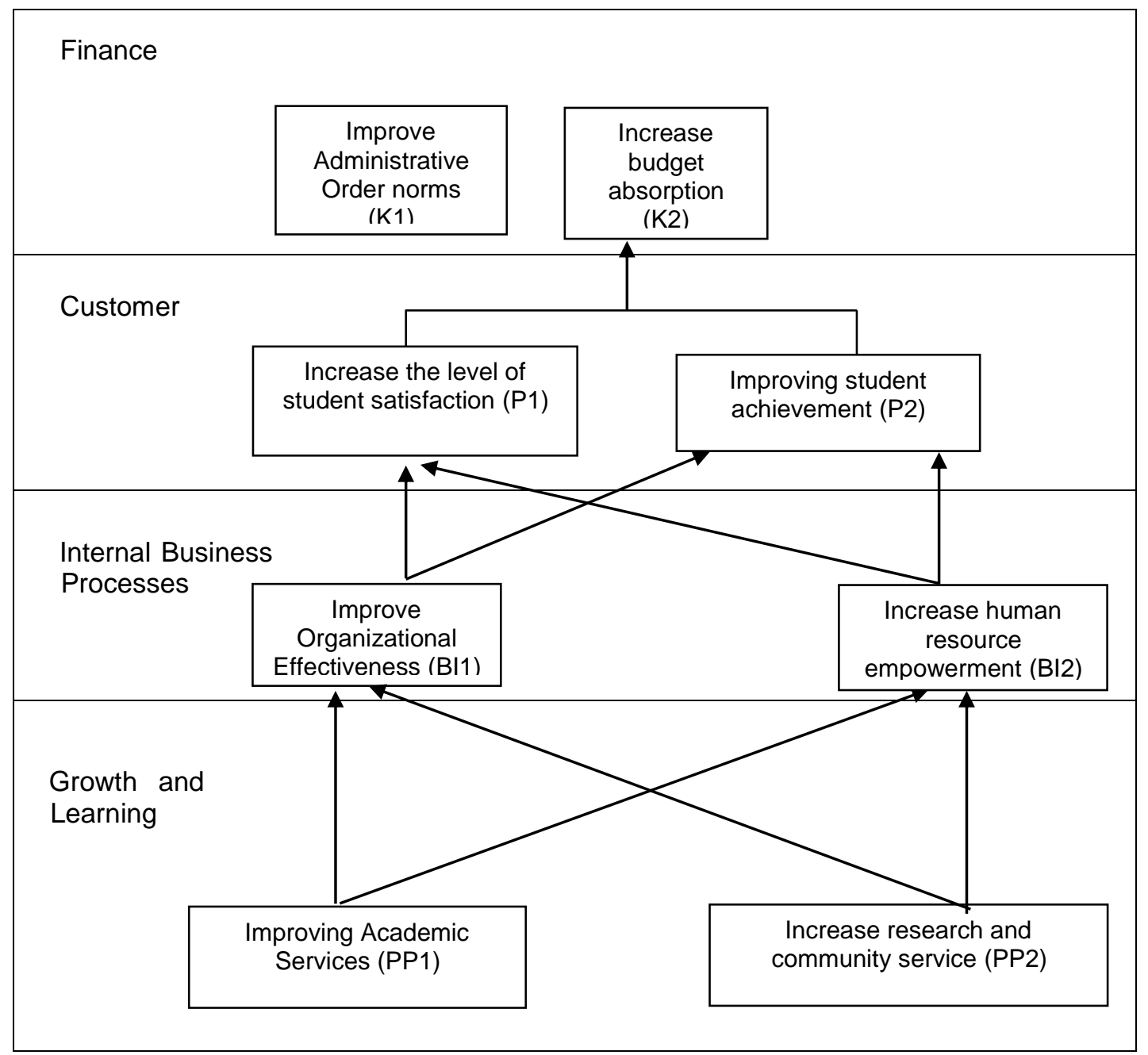




\section{d. Company Scorecard}

In the final stage of performance measurement, a company scorecard must be built which is obtained by mapping the balanced scorecard perspective relationship, strategic areas, strategy grid, with the vision, mission and strategy of the company / institution.

Table 4 Implementation of the company scorecard at the Naval Academy.

\begin{tabular}{|c|c|c|c|c|}
\hline \multirow[b]{2}{*}{ No } & \multirow[b]{2}{*}{ Strategic target } & \multicolumn{3}{|c|}{ Strategic Measures } \\
\hline & & Size of Results (Lag Indicator) & Push Size (Lead Indicator) & \multirow{2}{*}{$\begin{array}{c}\begin{array}{c}\text { Achievement } \\
\text { Targets }\end{array} \\
100 \%\end{array}$} \\
\hline 1 & $\begin{array}{ll}\text { Increase } & \text { Budget } \\
\text { Absorption } & \\
\end{array}$ & $\begin{array}{l}\text { Implementation of work programs on } \\
\text { time }\end{array}$ & There is no remaining budget & \\
\hline 2 & $\begin{array}{l}\text { Improve } \\
\text { Administrative Order } \\
\text { norms }\end{array}$ & $\begin{array}{l}\text { Implementation of an Accountable } \\
\text { Work Program }\end{array}$ & $\begin{array}{l}\text { Minimize the number of } \\
\text { findings }\end{array}$ & $100 \%$ \\
\hline 3 & $\begin{array}{l}\text { Increase the } \\
\text { satisfaction and } \\
\text { motivation of cadets }\end{array}$ & Cadet satisfaction index & Reduced number of complaints & $\geq 90 \%$ \\
\hline \multirow[t]{4}{*}{4} & \multirow{4}{*}{$\begin{array}{l}\text { Improving student } \\
\text { achievement }\end{array}$} & Students graduate on time & (Youth satisfaction survey) & $100 \%$ \\
\hline & & $\begin{array}{l}\text { Graduates who get a GPA of } 3 \text { on a } \\
\text { scale of } 4\end{array}$ & $\begin{array}{ll}\text { Students } & \text { graduate } \\
\text { satisfactorily } & \end{array}$ & $\geq 90 \%$ \\
\hline & & Paper publication & Number of papers published & \\
\hline & & Student Kesamaptaan & $\begin{array}{l}\text { The ratio of students who } \\
\text { graduated the same }\end{array}$ & $100 \%$ \\
\hline \multirow[t]{4}{*}{5} & \multirow{4}{*}{$\begin{array}{l}\text { Improve } \\
\text { organizational } \\
\text { effectiveness }\end{array}$} & Procurement process & $\begin{array}{l}\text { Realization of development } \\
\text { planning }\end{array}$ & $80 \%$ \\
\hline & & Fulfillment of Personnel & $\begin{array}{l}\text { Fulfillment of TNI and PNS } \\
\text { Personnel }\end{array}$ & $100 \%$ \\
\hline & & Settlement report see BMN & $\begin{array}{l}\text { Completion of the report See } \\
\text { BMN }\end{array}$ & $100 \%$ \\
\hline & & $\begin{array}{lll}\begin{array}{l}\text { Increased } \\
\text { capabilities }\end{array} & \text { information system } \\
\end{array}$ & $\begin{array}{l}\text { The level of information system } \\
\text { capability }\end{array}$ & $100 \%$ \\
\hline \multirow[t]{6}{*}{6} & \multirow{6}{*}{$\begin{array}{l}\text { Increase human } \\
\text { resource } \\
\text { empowerment }\end{array}$} & Increased Discipline & $\begin{array}{l}\text { Reducing the number of } \\
\text { Personnel Violations }\end{array}$ & $0 \%$ \\
\hline & & Awards & $\begin{array}{l}\text { Ratio of promotion compared } \\
\text { to proposal }\end{array}$ & $100 \%$ \\
\hline & & $\begin{array}{l}\text { Achievement of } \mathrm{HR} \text { training and } \\
\text { development programs }\end{array}$ & Number of training that is done & $100 \%$ \\
\hline & & Personnel Personnel & Increasing the Value of Peace & $100 \%$ \\
\hline & & Personnel Attendance & $\begin{array}{l}\text { The level of attendance of } \\
\text { personnel }\end{array}$ & $90 \%$ \\
\hline & & Employee satisfaction and motivation & $\begin{array}{l}\text { Level of employee satisfaction } \\
\text { and motivation }\end{array}$ & $\geq 90 \%$ \\
\hline \multirow[t]{7}{*}{7} & \multirow[t]{7}{*}{$\begin{array}{l}\text { Improve Academic } \\
\text { Services }\end{array}$} & The functioning of the lecture facilities & $\begin{array}{l}\text { There was no damage to the } \\
\text { facility }\end{array}$ & $80 \%$ \\
\hline & & $\begin{array}{l}\text { Availability of curriculum support } \\
\text { references }\end{array}$ & Number of books available & $75 \%$ \\
\hline & & & Lecturer attendance level & $90 \%$ \\
\hline & & The presence of lecturers in teaching & Improved existing software & $100 \%$ \\
\hline & & $\begin{array}{l}\text { Quality improvement of teaching } \\
\text { methods }\end{array}$ & $\begin{array}{l}\text { Improved } \quad \text { Manufacturing } \\
\text { Instructions Package }(\mathrm{PI})\end{array}$ & $80 \%$ \\
\hline & & Curriculum Improvement & $\begin{array}{l}\begin{array}{l}\text { Number of laboratories } \\
\text { available }\end{array} \\
\end{array}$ & $80 \%$ \\
\hline & & Laboratory Availability & Fulfillment of Alins required & $100 \%$ \\
\hline \multirow[t]{3}{*}{8} & \multirow{3}{*}{$\begin{array}{l}\text { Increase research } \\
\text { and community } \\
\text { service }\end{array}$} & Adding Alins & $\begin{array}{l}\text { The amount of community } \\
\text { service done }\end{array}$ & $100 \%$ \\
\hline & & Achievement of community service & Number of studies conducted & $100 \%$ \\
\hline & & Achievement in the number of studies & $\begin{array}{l}\text { Number of collaborations } \\
\text { carried out }\end{array}$ & $100 \%$ \\
\hline
\end{tabular}

\section{CONCLUSION}

The conclusions that can be drawn after applying the Balanced Scorecard method to design a performance measurement system at the Naval Academy are as follows:
The balanced scorecard can be applied in the design of performance measurement systems at AAL and the framework carried out in this study can facilitate the implementation of the balanced scorecard as a performance measurement tool at AAL. 


\section{REFERENCES}

Ahmadi. (2017). Design of Kinerjka Measurement System in Kolat Armatim with DEMATEL, ANP and Intergrated Performance Measurement System (IPMS) Approaches. ASRO JOURNAL-STTAL, 1-14.

Aisyati, A. (2012). Performance Measurement Model Using the Integrated Performance Measurement Systems and Analytical Hierarchy Process Methods. Performance, Vol. 11, No. 1: 23-30.

Ciptomulyono, U. (2008). Application of MCDMAnalytic Network Process (ANP) and Balanced Scorecard Method for Performance Measurement. Journal Of Technoscientia Technology, 121-130.

Falatoonitoosi, E. Z. (2012). Casual Mapping Strategy Using Integrated BSC and MCDMDEMATEL. Journal of American Science, 8 (5).

Gaspers, V. (2002). Integrated Performance Management System Balanced scorecard with Six Sigma for Business and Government Organizations. Jakarta: Gramedia.

Girikallo, A. S. (2017). Performance Management System of Private Higher Education Institutions in Indonesia. Journal of Management \& Business, 65-79.

Hori, S.. (1999). Designing methods of human interface for supervisory control systems. Control Engineering Practice 7 (11), 14131419.

I. Yüksel, M. D. (2010). Using the fuzzy analytic network process (ANP) for the Balanced Scorecard (BSC). Expert Systems with Applications 37 (2010), 1270-1278. llyas, Y. (2000). Performance Assessment and Research Theories. Jakarta: FKMUI Health Economics Study Center.

Kaplan Robert S, N. (1996). The Balanced Scorecard Translatin Strategy into action. Harvard Business Review.

Kaplan, R. S. (1992). The Balanced ScorecardMeasure that Drive Performance. Massachusetts: Harvard Business Review.

Luis, P. B. (2008). Step by Step in Cascading the Balanced Scorecard to Functional Scorecard. Jakarta: PT. Gramedia Main Library.

Moghaddam, N. B. (2010). Strategic Environment Analysis Using the DEMATEL method Through Systematic Approach: Case Study of an Energy Research Institute in Iran. Management science and engineering, Vol 4, No. 4, 95-105.

Mulyadi, J. S. (2001). Management Planning and Control System: Corporate Performance Multiplying System. Jakarta: Salemba Empat.

Pertiwi, A. P. (2014). Balanced Scorecard as a College Performance Measurement Tool (IT TELKOM).

https://www.researchgate.net/publication/2 36014376.

Saaty. (1993). Decision Making For Leaders (Translation). Jakarta: PT. Binaman Pressindo Library.

Saaty, T. L. (2003). "Decision Making For Leaders" (Translation). Jakarta: PT. Binaman Pressindo Library. 